\title{
THE MANIFESTATIONS OF ORGANISATIONAL CITIZENSHIP BEHAVIOUR. THE PERSPECTIVE OF THE INTERNAL CUSTOMER
}

\author{
Bolesław Goranczewski*
}

\begin{abstract}
Background. The article focuses on two intrapersonal factors having a significant impact on the idea of the internal customer and the existence or absence of organisational citizenship behaviour. These factors are altruistic and egoistic attitudes.

Research aims. The main objective of the analysis presented in the article is to describe manifestations of organisational citizenship behaviour from the perspective of the internal customer.

Methodology. The article is based on the study of the literature on this subject. It also has the character of a conceptual review. The reflections included in the article result from the author's many years of practical managerial experience in the use of such techniques as participant observations, interviews, analyses of intraorganisational source documentation and others. Thus the article contains the attributes of research based on the ethnographic method.
\end{abstract}

Key findings. The author characterises five personality types of the internal customer in the context of organisational citizenship behaviour. The first type is the "altruist". The second type is the "neutral". It represents the internal customer who is half an altruist and half an egoist. The "egoist" is the third type of the internal customer who functions in two dimensions. The egoist adopts positive behaviour only in return for an award. This type of an internal customer represents also behaviour which is apparently positive (counterproductive). The fourth fifth type is the internal customer who, restricted internally or externally, does not adopt citizenship behaviour. The conclusions of the article present possible problems and questions which could constitute a starting point for further research on organisational citizenship behaviour from the perspective of the internal customer.

Key words: internal customer, internal supplier, internal product, organisational citizenship behaviour

\footnotetext{
"WSB University in Wrocław. E-mail: boleslaw.goranczewski@wsb.wroclaw.pl.
} 


\section{INTRODUCTION}

Improving the effectiveness of organisations has always been the factor attracting special attention of both practitioners and theoreticians of management. The subject matter of this article is an analysis of the interdependence between the category of the internal customer in organisations and organisational citizenship behaviour, i.e. the two constructs which undoubtedly exert considerable influence on management effectiveness. The necessary condition, however, is to create a favourable organisational environment making it possible for the two categories to occur. The concept of the internal customer can be analysed on the basis of different approaches such as, for example, the subjective approach, the functional approach or the process approach (Bugdol, 2011; Goranczewski, 2017). Citizenship behaviour belongs to the area of the unwritten rules of interpersonal coexistence and has a positive impact on the creation of an enterprise's value chain (MacKenzie, Podsakoff, \& Fetter, 1993).

In view of the fact that organisational citizenship behaviour contributes to the improvement in the effectiveness of an organisation, the question arises whether organisations can create conditions favouring the existence of such behaviour. The best environment for such conditions is provided by organisations which are "faithful" to the quality culture. They constitute a good foundation for the appearance of organisational citizenship behaviour. This is so because organisations oriented towards quality are aware of the importance of good organisational results manifesting themselves in the satisfaction of the external customer and of the influence exerted by the internal customer participating in the processes of creating added value on such results. They are also aware of the necessity of remunerating employees fairly for the effects of their work (Krodkowska-Skoczylas, \& Żarlicka, 2006).

Treated differently by different authors and researchers, the category of the internal customer is more obscure (enigmatic). As every customer, also the internal one, should be treated in a particular way, what becomes important is an evaluation of the extent to which such qualities as altruism or egoism influence the attitudes of the internal customer in the work environment. And in this context, the internal customer is understood narrowly as a co-worker who receives an internal product. 
The category of the internal supplier is inseparably connected with the internal customer because within the idea of the internal customer there occurs a strong dualism of roles. In the organisational environment we are all both an internal customer and an internal supplier. Preparing particular tangible or intangible goods for our co-workers, we create internal products with which our internal customers are satisfied or not.

An analysis of the internal customer from the perspective of organisational citizenship behaviour may concern the following two opposing contexts:

- the limitation of organisational citizenship behaviour in view of the necessity to fulfil the formal requirements guaranteeing that the internal customer will always be provided with a product of the same quality; this applies mainly to procedures and instructions determining execution standards at the particular work stages; it is necessary to follow strictly the required standards in order to create a repeatable internal product which meets the expectations of the internal customer; hence the context of limitation comprises repeatable and formalised activities where decisions are preprogrammed,

- $\quad$ an accelerator/generator of citizenship behaviour in view of the fact that the satisfaction of the customer, including the internal customer, should be the basic determinant of organisational activities; this applies in particular to operations which are not excessively formalised by internal and external regulations, non-routinised operations where the internal product has the form of know-how, good practices, ideas, concepts as well as projects, team work, etc.

The article deals with the manifestations of organisational citizenship behaviour from the perspective of the internal customer. As far as the internal customer is concerned, to date there has been no research aimed at reviewing and summarising the literature on this particular subject. There has been no meta-analysis which would take into consideration the attribute of the accumulation of previous research results or analysis of the content of published materials. An exception is an attempt to present such a summary undertaken by the author of this article (Goranczewski, 2017). There is no standard science-based definition of the internal customer which would be accepted by researchers specialising in this subject by consensus. 
Hence we have to deal with the ambiguous, subjective, and implied understanding of the essence of the internal customer represented by particular researchers as well as a considerable degree of eclecticism in the methodology of explaining and describing this notional category. In Poland there are practically no scholarly publications on the internal customer based on research or analysis of a conceptual, rather than a journalistic, character.

With respect to organisational citizenship behaviour, the situation is different as this category has been the subject of extensive research (Podsakoff, MacKenzie, Paine \& Bachrach, 2000). However, the number of academic publications on this subject in Poland is rather insignificant.

Reviewing available databases concerning scholarly publication, one can conclude that so far the interdependence between the two constructs has not been the subject of any research or publication of a conceptual character. Therefore, this article is undoubtedly innovative.

It describes five personality types of the internal customer in the context of organisational citizenship behaviour. Each type of the personality of the internal customer has a particular influence on the creation of a value chain in a business enterprise and finally, with respect to each personality type, organisations should use relevant instruments of exerting influence. The article takes into consideration the humanistic context, indicating individuals' attitudes, expectations, and behaviours which are of a subjective, sometimes irrational, or egoistic, nature.

For the purpose of ensuring order in the identification (conceptual) process underlying this article, the following hypotheses have been adopted:

H1: the interdependence between the internal customer and organisational citizenship behaviour has an intrapersonal basis related to values,

$\mathrm{H} 2$ : the aforementioned interdependence has also an interpersonal character occurring in interactions between the internal customer and the internal supplier,

H3: in the subjective approach, the actions of the internal customer (understood as an employee) are based on their egoism, altruism, or an individual combination of these two qualities.

The reflections included in the article result from the author's many years of practical managerial experience in the use of such techniques 
as participant observations, self-observations, interviews, analyses of intraorganisational source documentation and others, which fulfils the attributes of research based on the ethnographic method (Kostera, 2003; Zawadzki, 2015; Holman, \& Jones, 2014).

\section{THE INTERNAL CUSTOMER}

The available literature on the subject of the internal customer is relatively scarce (e.g. Hauser, Simester, \& Wernerfelt, 1996; Brooks, Lings, \& Botschen, 1999; Jun, \& Cai, 2010; Gurjeet, Shanna, \& Seli, 2008; Mosahab, Mahamad, \& Ramayah, 2010). The definitions of the internal customer presented in publications in various languages are coincident with the normative definition included in the terminological standard. The standard presents the following definition: a customer is "an organization which or an individual who receives a product. With respect to an organisation, a customer may be internal or external" (PN-EN ISO 9000:2006, item 3.3.5). This also applies to the supplier and the internal product.

Thus, the domestic literature on the subject is based on the aforementioned standard. K. Opolski claims that, according to the philosophy of quality management, besides knowing its external customers, the organisation should also get to know its internal customers, that is customers who receive the results of work performed by other units within the organisation. The organisation is not able to meet the expectations of its external customers if the results of work delivered to internal customers are unsatisfactory (Opolski, 2002).

E. Tabaszewska perceives the internal customer as "a person functioning within an organisation", who acquires the effects of work from another co-worker and subsequently adds their own contribution to the received product. The enriched product is then relayed to another worker. Thus the internal customer contributes to the development of a value chain which is ultimately received by the external customer (Tabaszewska, 2007).

M. Morawski and G. Kobyłko are of the opinion that if organisations are to use the concept of the internal value chain and the internal customer, they need to shape their culture to ensure general awareness of the following: firstly, every piece of work is a process; secondly, we are customers when we receive materials, information, or services 
from other people in a given organisation or from the outside; thirdly, we are suppliers when we provide things or services; fourthly, information, materials, or services which we as suppliers deliver to others constitute outputs in the chain of relationships among suppliers and recipients, and when we fulfil our duties well, we add new value to the received input; fifthly, customers and suppliers exchange information in order to adjust their operations to the recipient's requirements or to communicate their own requirements (Morawski, \& Kobyłko, 2006).

According to A. Iwasiewicz, an internal customer is every recipient of the results of work performed by their predecessors in a technological chain. In a business enterprise there are many situations in which particular divisions or individuals deliver each other products - such recipients are frequently referred to as internal customers, even though, they are not customers in the narrow sense of the term (Iwasiewicz, 1999).

So far the only cohesive work on the subject of the internal customer has been published by M. Bugdol, who indicates that internal customers comprise, among others, an employee and/or a group of employees; another process in a value chain or relationships occurring within functional connections resulting from the organisational structures (Bugdol, 2011).

Analysing the results of the studies on the internal customer conducted so far, we can distinguish the following three basic research trends:

- the internal customer from the perspective of internal marketing understood as the transposition of the market rules and principles prevailing outside the organisation to its inside; where researchers deal with suppliers, internal products, and internal customers and where relationships oriented towards customers and taking place between the organisation and the external customer are the same with respect to the internal customer; researchers focus primarily on the awareness of the external customer within the organisation as well the needs and expectations of the external customer in the context of the awareness of internal market's functioning (e.g. Tortosa-Edo, Sanchez-Garcia, \& Moliner-Tena, 2010; Conduit, \& Mavondo, 2001);

- the internal customer as an employee; it is a narrow interpretation understood interpersonally which does not include social groups or other stakeholders, for example trade unions, regarded 
as counterorganisations which also have their own needs and expectations from the organisation and express their satisfaction or dissatisfaction with the degree to which such needs are met; in this trend, researchers focus mainly on the examination of job satisfaction, considering the category of the internal customer as one belonging to the human resource approach; most researchers assume a priori that the internal customer is an employee without explaining their individual understanding of this notional category; it can be assumed that many of them interpret this category completely differently; furthermore, it is an excessive simplification and a methodological error; equating the internal customer exclusively with the employee, the lack of any semantic distinction between these two notional categories causes disorder and cognitive chaos because the questions arise about the reason for the authors' introducing an indeterminate category of internal customer into research on customer satisfaction, which is the domain of human resource management as one of the subdisciplines of science and about the demarcation line between the employee and the internal customer if in both cases it is job satisfaction that constitutes the subject matter of research (e.g. Chaston, 1994; Pryor, Toombs, Anderson, \& White, 2010);

- the satisfied internal customer, but from the perspective of the quality of an internal product; within this trend, researchers concentrate mainly on examining the quality of internal goods (products and services); the decisive majority of them try to adapt the proven quality research methods such as Servqual, QFD, and the Kano questionnaire or to conduct their validation in the context of internal customer satisfaction (e.g. Brooks, Lings, \& Botschen, 1999; Hauser, Simester, \& Wernerfelt, 1996; Minjoon, \& Shaohan, 2010).

On the basis of the available literature on the subject, the author's own research and practical experience, the internal customer in the broad sense should be considered in the following three dimensions (Goranczewski, \& Puciato, 2010; Goranczewski, 2011; Goranczewski, \& Szeliga-Kowalczyk, 2016; Goranczewski, 2017):

- an internal stakeholder: a co-worker receiving a tangible or intangible product; an owner or shareholder; a social partner, etc., 
- entities in organisational structures in functional and capital relationship within a group of companies, a multi-division enterprise, etc., functional departments in an individual entity; individual organisational units; employment positions,

- sequential and/or parallel processes where output data from the preceding process constitute an internal product for the following process and simultaneously its input data.

The idea of the internal customer is characterised by the dualism of roles. In an organisation, everybody is at the same time both an internal customer and an internal supplier. The frequency with which these roles change depends on the type of organisation as well as many other situational factors.

\section{THE ESSENCE OF ORGANISATIONAL CITIZENSHIP BEHAVIOUR}

The notion of organisational citizenship behaviour appeared for the first time in the 1970s. Since then the popularity of this construct has been growing constantly the result of which is various and numerous researches on organisational citizenship behaviour (e.g. Chwalibóg, 2012; Organ, Podsakoff, \& MacKenzie, 2006; Miroński, \& Czaplińska, 2010; Podsakoff, MacKenzie, Paine, \& Bachrach, 2000). The interest in this notion is strongly connected with the fact that the manifestation of citizenship behaviour, whose character is uniquely pro-social and cooperative, by members of organisations exerts a positive impact on the effectiveness of organisations.

Nowadays, organisational citizenship behaviour is defined the most frequently as behaviour initiated voluntarily, on one's own initiative, during and/or outside working time, which exceeds the scope of formal duties, irrespective of whether it will be rewarded or not. A "citizen" does not expect a reward; a reward does not determine a "citizen's" behaviour. Hence (helpful) behaviour which is positive but dependent on the reception of a reward cannot be classified as organisational citizenship behaviour. One cannot be rewarded for citizenship behaviour or punished for the lack thereof (Organ, 1988; Organ, Podsakoff, \& MacKenzie, 2006). However, an organisation may foster the occurrence of citizenship behaviour (for example by means of examples coming from the top or rewards which are not included in 
the formal remuneration system) or effectively hinder organisational citizenship behaviour, for example by denouncing them. What needs to be taken into consideration is the fact that the use of formal and fair remuneration systems may facilitate employees' positive behaviour which was rewarded in the past (dependent on rewards), which, in turn, creates a work atmosphere favouring the occurrence of organisational citizenship behaviour.

All researchers agree that the fundamental assumption of the concept is that organisational citizenship behaviour has a multidimensional character consisting of various behavioural categories. This article presents the categories of organisational citizenship behaviour (Table 1) distinguished by Podsakoff and LePine, i.e. helping, commitment, organisational loyalty, individual initiative, organisational obedience, and self-development.

Table 1. The categories of organisational citizenship behaviour according to Podsakoff and LePine

\begin{tabular}{|c|c|c|}
\hline \# & $\begin{array}{l}\text { Dimensions of } \\
\text { organisational } \\
\text { citizenship } \\
\text { behaviour }\end{array}$ & Description \\
\hline 1. & Helping & $\begin{array}{l}\text { It consists in preventing voluntarily the occurrence of problems } \\
\text { related to job duties, e.g. assisting new employees to adapt, sup- } \\
\text { porting employees overburdened quantitatively and/or qualitatively } \\
\text { with work, etc. }\end{array}$ \\
\hline 2. & Commitment & $\begin{array}{l}\text { It consists in participating voluntarily in all types of matters con- } \\
\text { nected with the organisation, e.g. participating in non-obligatory } \\
\text { meetings, carrying out additional tasks, etc. }\end{array}$ \\
\hline 3. & $\begin{array}{l}\text { Organisational } \\
\text { loyalty }\end{array}$ & $\begin{array}{l}\text { It consists in promoting the organisation's positive image on the out- } \\
\text { side, e.g. defending the organisation's image in crisis situations, etc. }\end{array}$ \\
\hline 4. & $\begin{array}{l}\text { Individual } \\
\text { initiative }\end{array}$ & $\begin{array}{l}\text { It consists in undertaking innovative and creative activities going } \\
\text { beyond the scope of duties at a particular position, e.g. getting } \\
\text { involved in projects being executed by other teams, sharing ideas to } \\
\text { improve the operational effectiveness of the team and consequently } \\
\text { the organisation as a whole, etc. }\end{array}$ \\
\hline 5. & $\begin{array}{l}\text { Organisational } \\
\text { obedience }\end{array}$ & $\begin{array}{l}\text { It consists in accepting, complying with and promoting the organ- } \\
\text { isation's internal formal requirements among co-workers without } \\
\text { any supervision of superiors, e.g. complying with the length of } \\
\text { breaks, using working time efficiently, etc. }\end{array}$ \\
\hline 6. & $\begin{array}{c}\text { Self- } \\
\text { development }\end{array}$ & $\begin{array}{l}\text { It is internal motivation to develop one's own skills and competenc- } \\
\text { es as well as to broaden one's knowledge related to professional } \\
\text { duties and to acquire new skills which may contribute to the } \\
\text { increased the effectiveness of performed work. }\end{array}$ \\
\hline
\end{tabular}

Source: prepared on the basis of Organ, D.W., Podsakoff, P.M., MacKenzie, S.B. (2006). Organizational Citizenship Behavior: Its Nature, Antecedents, and Consequences. London-New Dehli: Thousand Oaks, SAGE Publications. 
Numerous researchers confirm that the aforementioned categories of organisational citizenship behaviour have an undeniable influence on the development and effectiveness of individuals, teams and organisations as a whole; in particular such behaviour:

- contributes to decreasing differences in the levels of performed tasks and achieved results as well as improves abilities to accept and adjust to changes taking place in the organisation (Podsakoff, \& MacKenzie, 1997),

- contributes to attracting and retaining the best employees (George, \& Bettenhausen, 1990),

- improves the productivity of co-workers and the management (Smith, Organ, \& Near, 1983).

It should be noted that the types of behaviour specified in the table above are of an individualised nature. The creation of organisational conditions favourable for the occurrence of organisational citizenship behaviour does not suffice if an organisation's members/ employees are not properly predestined for such behaviour. Personal predispositions are determined by an individual's social development, previous experiences, upbringing, acquired skills, knowledge, etc. For example, the need to help others is developed the most often at the stage of upbringing. It may be anticipated and shaped in the subsequent period, but the predisposition acquired in this way may not be permanent or may depend on opportunistic factors (I will help you in return for a particular benefit). A wide range of social dysfunctions faced by contemporary organisations, particularly large corporations, or the dynamics of conducting business in the modern world cause the work environment to be oriented towards competition rather than cooperation (Szeliga-Kowalczyk, 2016). And competition is counterproductive with respect to the need to help, while in the case of commitment, it is closely dependent on motivation. If an employee's existential or other important needs are not fulfilled, commitment is out of the question. The same applies to such dimensions of organisational citizenship behaviour as organisational loyalty, individual initiative or obedience. Without support and proper motivation, it is difficult to imagine employees' taking care of the employer's image or committing themselves to stand up for their organisation, particularly in critical situations, e.g. when its reputation or image is at stake. On the other hand, all initiatives going beyond the scope of official duties, the attitudes of openness 
and sharing knowledge with co-workers, the generation of new ideas, participation in the activities of other groups or work teams, the development of skills and competences and finally all ideas related to vocational improvement are doomed to failure without strong embedment in the foundation of effective motivation.

Attitudes related to commitment, organisational loyalty, initiative, or self-development have their source in both motivation and individual predispositions. As far as organisational obedience is concerned, it has an obligatory character independent of individual motivations or predispositions. Everybody has to maintain work discipline and comply with formal requirements (external and internal regulations) effective in the organisation. Without motivation, however, organisational obedience will have a phoney/illusory character which cannot inspire trust. The category of trust to be translated into commitment, satisfaction, quality, productivity, or a sense of fairness is a fundamental condition determining the appearance of organisational citizenship behaviour (Bugdol, 2010).

Therefore, together with good upbringing and individual predispositions, a proper motivational system creates an inseparable triad of factors determining the occurrence of organisational citizenship behaviour. While upbringing or individual predispositions are characterised by subjectivism and freedom from the influence of an organisation, a fair, and effective motivational system which is oriented toward efficiency and takes into consideration the context in which an organisation functions can be and should be the work of the organisation itself.

Thus organisational citizenship behaviour appears as a specification of ideal attitudes which, were they to appear in the environment of a particular organisation, would have a significant impact on its success.

\section{THE MANIFESTATIONS OF ORGANISATIONAL CITIZENSHIP BEHAVIOUR FROM THE PERSPECTIVE OF THE INTERNAL CUSTOMER}

It should be accepted that organisational citizenship behaviour should be considered in the subjective dimension only because it is only man who decides to adopt or not particular types of behaviour. It is difficult to analyse organisational citizenship behaviour in the context of 
a process analysis (a supplier process $\rightarrow$ a customer process) or based on a functional approach (a supplier organisational unit $\rightarrow$ a customer organisational unit), although it is not impossible in view of the fact that all activities within the scopes of processes or organisational units are performed by people. Hence the subjective dimension will concern the internal customer understood as an internal stakeholder:

- from the intrapersonal point of view, together with their convictions, values, and personality, and

- from the interpersonal point of view, in relationships between the supplier and the internal customer.

With respect to organisational citizenship behaviour, the subjective dimension may be described as a dynamic dimension of reactions taking place inside the internal customer (the way in which they are perceived by an individual) and simultaneously dynamic relationships between the internal supplier and the internal customer which influence the occurrence or the lack of citizenship behaviour. The internal customer (the internal stakeholder) has their own needs/expectations (requirements) within the context of citizenship behaviour. Such needs may be:

- purely altruistic (the idealist approach),

- a "mixture" of altruism and egoism (neutral), or

- purely egoistic, with the egoistic attitude generating either positive or negative consequences for a given organisation.

Taking into consideration the aforementioned division of the needs of the internal customer from the subjective point of view and their consequences for an organisation within the context of organisational citizenship behaviour, we can propose the following five-part classification of the internal customer (personality types):

1. The internal customer altruist.

The internal customer altruist is a citizen, an idealist. J. Poleszczuk claims that within the context of altruism there may occur such attitudes as helping in every situation, conditional helping, and extreme non-helping or egoism (Poleszczuk, 2004). This type of the internal customer adopts organisational citizenship behaviour towards other internal customers and suppliers as well as the organisation itself. It is characteristic that such behaviour is adopted voluntarily, on one's own initiative, during and/or outside working time, exceeds the scope of formal duties, irrespective of whether it will be rewarded or not. From the point of view of the organisation, such behaviour deserves 
the highest praise and appreciation on the part of superiors. The organisation may benefit a lot from the internal customer altruist, who exerts a positive impact on the shaping of the organisation's internal value chain. The internal customer altruist expects that products to be received from internal suppliers will be delivered with great dedication. Being an altruist, however, the internal customer is able to help internal suppliers when they cannot cope with product or service delivery processes. They are open to cooperation with internal suppliers and treat them with understanding. The internal customer altruist performs their duties well, adds new values to the processes in which they participate. With respect to the attribute of role transformation, internal products created by the internal customer altruist, who is simultaneously an internal supplier, represent a high level of quality because they are based on the values which may also be exemplified by organisational citizenship behaviour. This type of the internal customer does not expect rewards; a reward does not imply a particular type of citizen behaviour.

2. The "neutral" internal customer - half altruist/half egoist.

The internal customer half altruist/half egoist is the so-called "pseudo-citizen". They adopt positive behaviour at their place of work, but expect to be rewarded for this. They have good intentions, but are motivated by measurable benefits. For them, a reward is a determinant of adopting positive behaviour (they expect a financial or non-financial reward; they pursue their own interests/objectives). If there is no reward, a particular type of behaviour is terminated (a "pseudo-citizen"). This is a complex personality type. From the moment when no reward is given (a need remains unfulfilled) the "neutral" internal customer occasionally adopts positive behaviour, hoping to be appreciated. What prevails is the belief in the arrival of a reward (the egoistic attitude). Sometimes, if they feel like it, they may adopt a purely altruistic attitude. They help another internal customer or supplier, for example, to help them avoid problems at work or to improve the work process between them and the internal supplier. In such cases regard for friendliness towards selected people dominates over the attitude of selflessness, which, from the perspective of organisational citizenship behaviour, may be referred to as "partial altruism" or "reciprocated altruism" because it is not the organisation that constitutes a criterion of reference for such behaviour (Łomnicki, 2017). From the point of view of the organisation, such an attitude 
may be beneficial for the organisation on condition that it develops an effective/fair remuneration system. In view of the changeability of the roles (being simultaneously an internal customer and an internal supplier), the quality of both tangible and intangible internal products will depend closely on the status of the fulfilment of needs related to rewards or other benefits persuading people to adopt organisational citizenship behaviour. And what is important is a natural ability of this type of the internal customer to restore balance, that is to adopt organisational citizenship behaviour in a situation of experiencing a sense of motivation or self-esteem again.

3. The internal customer egoist (the positive dimension).

Similarly to the previous case, the internal customer egoist in the positive dimension is a "pseudo-citizen". This is a personality type which voluntarily adopts positive behaviour in their place of work. The main reason for adopting positive behaviour is a financial or non-financial reward, or some other benefits. Unlike the internal customer half altruist/half egoist, when the internal customer egoist is not rewarded, they terminate their organisational citizenship behaviour definitively. This concerns particularly people of narrow specialisations who know their own value, etc. From the point of view of the organisation, such an attitude may generate considerable benefits, but only if the organisation prepares an effective/fair remuneration system targeted at such individuals. Dissatisfaction, unfulfilled promises, and the simultaneous awareness of the role of significance of their work in the creation of added value may result in the attitude in which positive initiatives constituting the manifestations of organisational citizenship behaviour will not be undertaken. In such a situation, the quality of internal tangible or intangible products reflected in internal customer satisfaction or the lack thereof will depend exclusively on the degree to which internal procedures are formalised. And if an internal product depends to a considerable extent on the organisational climate, its quality will be lowered. This type of the internal customer will always expect high quality in internal products and services created and provided by committed suppliers manifesting organisational citizenship behaviour.

4. The internal customer egoist (the negative dimension).

The internal customer egoist in the negative dimension is a "sham". They fake organisational citizenship behaviour, which is detrimental to the organisation, but beneficial to them. They expect commitment and 
altruism from their internal suppliers, but concentrate on themselves (egocentrism) and benefits resulting from such an attitude. They do it at the cost of causing harm to others or in order to mislead others purposefully. A reward (even recognition from manipulated superiors) is an end in itself - the main reason for shamming organisational citizenship behaviour. Third parties (internal customers, suppliers, superiors, and subordinates) see a citizenship attitude in their behaviour, but they evidently harm the organisation, pursuing their own benefits. For example, they remain at work after hours, pretending to be committed and busy, in order:

- to avoid fulfilling their household duties - sham citizenship behaviour spreads outside the work environment towards private life (they manipulate their co-workers, superiors, and family),

- to pursue their hobbies, interests, informal contacts, e.g. through social media, the Internet, etc. (there are relatively easy methods of checking such attitudes by means of IT tools tracking people's activities on the Internet).

Attitudes of this type occur very frequently at managerial and independent positions because such positions provide more freedom with respect to formal restrictions, task performance methods, flexible working time, functional control, or the availability of infrastructure related to the discharge of duties. From the point of view of the organisation, such attitudes are counterproductive and thus highly undesirable. When such people are internal customers, they demand a lot, adopting claiming or even pretentious attitudes, simultaneously shamming the fulfilment of their own duties as internal suppliers. Furthermore, they tend to behave unethically, purposefully offering defective internal (tangible or intangible) products in order to achieve particular personal gains.

5. The internal customer who does not adopt organisational citizenship behaviour (the passive attitude).

There are three types of restrictions determining the adoption of the passive attitude by the internal customer within the context of citizenship behaviour:

- internal restrictions - the internal customer does not adopt citizenship behaviour in the organisation because they do not feel this is necessary, despite the fact that the organisation creates conditions necessary for such behaviour, rewards it, etc., 
- external restrictions - the internal customer does not adopt organisational citizenship behaviour in the organisation, although they feel it is necessary; the internal customer is restricted by the organisation, which does not create favourable conditions for such behaviour, e.g. internal customers/suppliers stigmatise organisational citizenship behaviour, etc.,

- internal and external restrictions - the internal customer does not adopt citizenship behaviour in the organisation, they have no such needs; additionally, the organisation does not create favourable conditions for such behaviour at the place of work, which results in the dehumanisation of interpersonal relationship, the weakening of empathy, commitment, trust, availability, etc.

In the context of the internal customer, the passive attitude is characterised by minimal expectations (determined by relevant standards) with respect to internal products. The same applies to the role of the supplier, especially in the situation when organisational citizenship behaviour is stigmatised as actions aimed at currying favour with superiors. The passive attitude reflects indifference caused by various factors such as:

- a lack of motivation,

- social dysfunctions present in the organisation (workoholism, mobbing, discrimination, stress resulting from qualitative or quantitative overwork and/or underwork) (Szeliga-Kowalczyk, 2016),

- organisational culture oriented towards competition instead of cooperation, etc.

\section{DISCUSSION, FINAL COMMENTS, AND GUIDELINES FOR FURTHER RESEARCH}

Organisational citizenship behaviour constitutes an idea whose objective should be to improve the quality of the work environment understood narrowly as a set of interpersonal relationships occurring among members of an organisation. It seems to be significant in view of the fact that the quality of the work environment should determine the quality of internal products delivered to internal customers. Everything depends on individual situational factors which are exemplified by a given organisation's culture constituting its inherent property. Summing up 
the above considerations, it should be indicated that the hypotheses put forward at the beginning of this article have been confirmed. It seems appropriate to examine the manifestations of organisational citizenship behaviour from the perspective of the internal customer and its impact on the development of the internal value chain with respect to the various personality types of the internal customer/supplier discussed above. It should be assumed that the joint occurrence of these two categories is determined by similar organisational conditions as well as conditions related to individual predispositions and behaviour.

An academic undertaking a research in a particular organisation, sector, or industry may formulate research objectives aimed at explaining the attitudes described above, for example:

1. Identifying conditions/reasons for the appearance or lack of organisational citizenship behaviour. Such conditions may include individual personality traits such as ability to make independent decisions and initiate actions, faith in one's own strength and potential, trust in one's own competences, etc. These may be cultural factors fostering or preventing the formation of organisational ties or a sense of fairness leading subsequently to commitment. The determinants of the occurrence of citizenship behaviour also include organisational factors among which the following deserve further examination: the degree of organisational formalisation; orientation towards functions versus orientation towards processes; individualism and collectivism in the performance of tasks; references to the sources of power (e.g. power resulting from control over knowledge, information, technique or technology; power resulting from connections and informal support, etc.) (Morgan, 2013).

2. The determination of the types of citizenship behaviour and the ways in which they are perceived by internal customers/suppliers (positive/negative perception). Described in the literature on the subject, the specification of organisational citizenship behaviour has a model character. There may be many more division and/ or reference criteria for such behaviour, for example:

- co-occurrence - some behaviour is of a uniform character and occurs independently; some behaviour is of a complementary or substitutive character; some behaviour is of a declarative character, in practice, it does not occur at all or occurs sporadically in organisations, 
- frequency - some types of behaviour occur very often, while other occur extremely rarely,

- usefulness - to what extent organisational citizenship behaviour translates into an organisation's economic effectiveness; how strongly such behaviour supports effective management.

3. The identification of the consequences of the lack of citizenship behaviour in a particular form, place, and time.

4. The occurrence of organisational citizenship behaviour in the context of the broad sense of the internal customer, thus: internal customer - a stakeholder, internal customer - a subject in the organisational structure (the functional approach); internal customer - process (the process-based approach).

Furthermore, for the further analysis of the research issues defined above, it is possible to formulate research questions, for example:

- In what (demographic, personality, organisational, psycho-social) conditions does the internal customer/supplier adopt organisational citizenship behaviour? How often is such behaviour adopted? What is the internal customer/supplier motivated by? Is it altruism, egoism, or any other determinants?

- In what circumstances does the internal customer/supplier witness organisational citizenship behaviour? How often do they notice such behaviour?

- What are the reasons for adopting a passive attitude towards organisational citizenship behaviour?

- What factors cause the internal customer/supplier not to notice organisational citizenship behaviour?

- How do internal customers/suppliers who are superiors treat the manifestations of organisational citizenship behaviour? Do they react positively/negatively to them? Do they reward, expect, force, or denounce them?

- How do internal customers/suppliers who are co-workers treat the manifestations of citizenship behaviour? Do they react positively/ negatively to them? Do they praise, appreciate, or denounce them?

- What consequences would the whole organisation expect if citizenship behaviour did not appear in a particular form, place, and time? 
Undoubtedly, there are many more criteria of reference for research into the idea of the internal customer in the context of organisational citizenship behaviour. Needs, intergroup tensions, ambitions, emotions, sensitivity to change, resistance to stress, unethical attitudes, counterproductive behaviour; the impact of these types of behaviour on the idea of the internal customer from the point of view of operational effectiveness and efficiency are examples of such research opportunities. Presented in this article, the classification of the internal customer from the perspective of organisational citizenship behaviour, from the altruist through the neutral and passive types to the egoist with a positive dimension and a negative dimension, shows the complexity of the highly individualised human nature in the work environment, determined by various motives and needs. It is characterised by the ambiguity, dualism, and sometimes irrationality of attitudes manifesting themselves in the individual's tendency to adopt organisational citizenship behaviour or to refrain from it. All this is of considerable importance and becomes reflected in internal products which the internal customer receives or benefits from. The internal customer's satisfaction or dissatisfaction with the received internal product, in turn, translates directly into the effectiveness and efficiency of the whole organisation.

\section{REFERENCES}

Brooks, R.F., Lings, I.N., \& Botschen, M.A. (1999). Internal Marketing and Customer Driven Wavefronts. Service Industries Journal, 19/4, 49-67.

Bugdol, M. (2010). Wymiary i problemy zarzadzania organizacja oparta na zaufaniu. Kraków: Wydawnictwo Uniwersytetu Jagiellońskiego.

Bugdol, M. (2011). Zarzadzanie pracownikami, klientami wewnętrznymi w organizacjach projakościowych. Warszawa: Difin.

Chaston, I. (1994). A Comparative Study of Internal Customer Management Practices Within Service Sector Firms and the National Health Service. Journal of Advanced Nurcing, 19, 299-308.

Chwalibóg, E. (2012). Rola menedżera w kształtowaniu zachowań obywatelskich w organizacji. In: A. Barabasz, E. Głuszek (eds.), Osobowościowe i kompetencyjne uwarunkowania sukcesu Prace Naukowe Uniwersytetu Ekonomicznego we Wrocławiu, 273, 9-19. 
Conduit, J., \& Mavondo, F. (2001). How Critical is Internal Customer Orientation to Market Orientation. Journal of Bussiness Research, 51, 11-24.

George, J.M., \& Bettenhausen, K. (1990). Understanding Prosocial Behavior, Sales Performance and Turnover: A Group-level Analysis in a Service Context. Journal of Applied Psychology, 75, 698-709.

Goranczewski, B. (2011). Klient wewnętrzny w zarządzaniu administracją publiczną. In: B. Goranczewski, K. Łobos (eds.), Wyzwania w zarządzaniu współczesną administracja. Zeszyty Naukowe Wyższej Szkoły Bankowej we Wrocławiu, $26,221-242$.

Goranczewski, B. (2011). Struktury i procesy w organizacjach ukierunkowanych na jakość. Prace Naukowe Wyższej Szkoły Bankowej w Gdańsku, 12, 35-57.

Goranczewski, B. (2017). Klient wewnętrzny. Analiza dotychczasowych kierunków i nurtów badawczych. In: M. Zajkowska (ed.), Potencjał innowacyjny i marketingowy współczesnych przedsiębiorstw. Prace Naukowe Wyższej Szkoty Bankowej w Gdańsku, 49, 181-198.

Goranczewski, B., \& Puciato, D. (2010). Wybrane aspekty idei klienta wewnętrznego w zarządzaniu przez jakość. In: W. Kieżun, L. Ciborowski, J. Wołejszo (eds.), Prakseologiczne aspekty zarzadzania we wspótczesnych organizacjach publicznych. Warszawa: Akademia Obrony Narodowej, 73-84.

Goranczewski, B., \& Szeliga-Kowalczyk, A. (2016). The Significance of Internal Customer Satisfaction in a Standardized Quality Management System in the Context of a Polish Higher Education Institution. Jagiellonian Journal of Management, 2(2), 107-128.

Gurjeet, K., Sharma, R.D., \& Seli, N. (2008). An Assessment of Internal Market Orientation in Jammu and Kashmir Bank Through Internal Suppliers' Perspective. Journal of Management Research, 7/2, 149-176.

Hauser, J.R., Simester, D.I., \& Wernerfelt, B. (1996). Internal Customers and Internal Suppliers. Journal of Marketing Research, 33/3, 268-280.

Holman Jones, S. (2014). Autoetnografia. In: N.K. Denzin, Y.S. Lincoln (eds.), Metody badań jakościowych. Warszawa: PWN, 175-218.

Iwasiewicz, A. (1999). Zarzqdzanie jakościq. Podstawowe problemy i metody. Warszawa: PWN.

Jun, M., \& Cai, Sh. (2010). Examining the Relationships Between Internal Service Quality and its Dimensions, and Internal Customer Satisfaction. Total Quality Management, 21/2, 205-223.

Kostera, M. (2003). Antropologia organizacji. Warszawa: PWN.

Krodkiewska-Skoczylas, E., \& Żarlicka, G. (2006). Zarządzanie relacjami z klientem. In: T. Sikora (ed.), Klient w organizacji zarzqdzanej przez jakość. Kraków: Akademia Ekonomiczna w Krakowie, 17-40. 
Łomnicki, A. (2017). Ekologia ewolucyjna. Warszawa: PWN.

MacKenzie, S.B., Podsakoff, P.M., \& Fetter, R. (1993). The Impact of Organizational Citizenship Behaviour on Evaluations of Salesperson Performance. Journal of Marketing, 57, 70-80.

Minjoon, J., \& Shaohan, C. (2010). Examining the Relationships Between Internal Service Quality and its Dimensions, and Internal Customer Satisfaction. Total Quality Management \& Business Excellence, 21(2), 371-382.

Miroński, J., \& Czaplińska, I. (2010). Organizacyjne zachowania obywatelskie - istota, znaczenie i uwarunkowania. In: P. Kulawczuk, A. Poszewiecki (eds.), Behawioralne determinanty rozwoju przedsiębiorczości w Polsce. Behawioralny wymiar przedsiębiorczości. Gdańsk: Fundacja Rozwoju Uniwersytetu Gdańskiego, 332-346.

Morawski, M., \& Kobyłko, G. (2006). Przedsiębiorstwo zorientowane na wiedze. Warszawa: Difin.

Morgan, G. (2013). Obrazy organizacji. Warszawa: PWN.

Mosahab, R., Mahamad, O., \& Ramayah, T. (2010). Comparison of Service Quality Gaps among Teachers and Students as Internal and External Customers. International Journal of Marketing Studies, 2/2, 13-20.

Opolski, K. (ed.) (2002). Doskonalenie jakości w bankach. Warszawa: CeDeWu.

Organ, D.W. (1988). Organizational Citizenship Behavior - The Good Soldier

Syndrome. Lexington, Massachusetts-Toronto: D.C. Heath and Company. Organ, D.W., Podsakoff, P.M., \& MacKenzie, S.B. (2006). Organizational Citizenship Behavior: Its Nature, Antecedents, and Consequences. London-New Delhi: Thousand Oaks, SAGE Publications.

PN-EN ISO 9000:2006 (2006). Systemy zarzadzania jakościa, podstawy i terminologia. Warszawa: PKN.

Podsakoff, P.M., \& MacKenzie, S.B. (1997). Impact of Organizational Citizenship Behaviour on Organizational Performance: A Review and Suggestions for Future Research. Human Performance, 10(2), 1-40.

Podsakoff, P.M, MacKenzie, S.B, Paine, J.B., \& Bachrach, D.G. (2000). Organizational Citizenship Behaviours: A Critical Review of the Theoretical and Empirical Literature and Suggestions for Future Research. Journal of Management, 26(3), 513-563.

Poleszczuk, J. (2004). Ewolucyjna teoria interakcji społecznych. Warszawa: Scholar. Pryor, G., Toombs, L., Anderson, D., \& White, C. (2010). What Management and Quality Theories are Best for Small Businesses? Journal of Management \& Marketing Research, 3, 20-32.

Smith, C.A., Organ, D.W., \& Near, J.P. (1983). Organizational Citizenship Behaviour: Its Nature and Antecedents. Journal of Applied Psychology, 68, 653-663. 
Silverman, D. (2007). Interpretacja danych jakościowych. Warszawa: PWN.

Sokołowska, S. (2004). Organizacja i zarzadzanie. Ujęcie teoretyczne. Opole: Wyd. Uniwersytetu Opolskiego.

Szeliga-Kowalczyk, A. (2016). Zmienność procesów a dysfunkcje społeczne w organizacji. Konferencja naukowa „W kierunku zarządzania procesowego organizacja. Trendy i wyzwania”. Szczecin: Uniwersytet Szczeciński, Szczecin, 20.05.2016.

Tabaszewska, E. (2007). Nowoczesne koncepcje zarzadzania-wyniki badań. Wrocław: Akademia Ekonomiczna.

Tortosa-Edo, V., Sanchez-Garcia, J., \& Moliner-Tena, A. (2010). Internal Market Orientation and its Influence on the Satisfaction on Contact Personnel. Service Industries Journal, 30(8), 1279-1297.

Zawadzki, M. (2015). Autoetnografia. In: M. Kostera (ed.), Metody badawcze w zarzadzaniu humanistycznym. Warszawa: Sedno, 61-70. 


\title{
PRZEJAWY ORGANIZACYJNYCH ZACHOWAŃ OBYWATELSKICH. PERSPEKTYWA KLIENTA WEWNĘTRZNEGO
}

\begin{abstract}
Abstrakt
Tło badań. W artykule skoncentrowano się na dwóch czynnikach intrapersonalnych majacych istotny wpływ na ideę klienta wewnętrznego oraz zaistnienie bądź nie organizacyjnych zachowań obywatelskich. Są nimi postawy altruistyczne i egoistyczne.
\end{abstract}

Cele badań. Głównym celem zaprezentowanej w artykule analizy jest przedstawienie przejawów organizacyjnych zachowań obywatelskich z perspektywy klienta wewnętrznego.

Metodologia. Artykuł oparty jest na badaniu literatury przedmiotu. Posiada także charakter przeglądowo-koncepcyjny. Refleksje w nim zawarte wynikaja $\mathrm{z}$ wieloletniego stosowania w praktyce zarządczej elementów takich technik, jak: obserwacja uczestniczaca, wywiady, analizy tekstów (dokumentacji źródłowych wewnattrzorganizacyjnych) i innych. Wypełnia to zatem atrybuty badania z zastosowaniem metody etnograficznej.

Kluczowe wnioski. Autor charakteryzuje pięć typów osobowości klienta wewnętrznego w kontekście organizacyjnych zachowań obywatelskich. Pierwszy typ to klient wewnętrzny „altruista”. Drugi typ „neutralny” - klient wewnętrzny, który w połowie jest altruista, w połowie egoista. Kolejny typ to klient wewnętrzny „egoista”, który funkcjonuje w dwóch wymiarach: podejmuje zachowania pozytywne jedynie za nagrodę lub w jego ramach występują również zachowania z pozoru pozytywne (kontrproduktywne). Piąty typ to klient wewnętrzny, który ograniczany wewnętrznie lub zewnętrznie nie podejmuje zachowań obywatelskich. W podsumowaniu artykułu przedstawiono możliwe problemy i pytania badawcze, które stanowić mogą punkt wyjścia do badań nad organizacyjnymi zachowaniami obywatelskimi z perspektywy klienta wewnętrznego.

Słowa kluczowe: klient wewnętrzny, dostawca wewnętrzny, produkt wewnętrzny, organizacyjne zachowania obywatelskie 